\title{
Assessment of Undiscovered Oil and Gas Resources in the Haynesville Formation, U.S. Gulf Coast, 2016
}

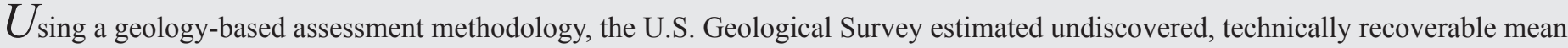
resources of 1.1 billion barrels of conventional oil and 195.8 trillion cubic feet of gas in the Upper Jurassic Haynesville Formation in onshore lands and State waters of the U.S. Gulf Coast region.

\section{Introduction}

The U.S. Geological Survey (USGS) assessed undiscovered, technically recoverable oil, gas, and natural gas liquids in the Upper Jurassic Haynesville Formation and stratigraphically equivalent units in the Gulf Coast from south Texas to the Florida Panhandle (fig. 1). The Haynesville Formation is part of the Upper Jurassic-Cretaceous-Tertiary Composite Total Petroleum System (TPS) in onshore lands and State waters of the U.S. Gulf Coast region. Strata in each assessment unit (AU) within a TPS share similar stratigraphic, structural, and petroleum-charge histories.

\section{Geologic Models for Assessment}

Mudstones within the Upper Jurassic Smackover and Haynesville Formations are sources of oil and gas in both conventional (Montgomery, 1993a, 1993b; Mancini and others, 2006) and continuous reservoirs (Hammes and others, 2011; Cicero and Steinhoff, 2013) throughout much of the assessment area. The conventional carbonate reservoirs of the Haynesville Formation in the western Gulf consist of lithofacies associated with deposition on a shallow marine shelf and include grainstone shoals/bars and local pinnacle reefs (Montgomery, 1993a). Conventional sandstone reservoirs in the eastern Gulf include lithofacies deposited in fluviodeltaic, marginal marine and marine shelf, slope, and basin floor settings (Montgomery, 1993b). Continuous mudstone reservoirs of the Haynesville Formation are interbedded with and (or) basinward of the Haynesville Formation carbonates (including the time equivalent Gilmer Limestone and Cotton Valley lime).

\section{Assessment Units}

Four Haynesville Formation AUs were assessed (fig. 1). In some locations, the conventional oil and gas AUs overlap with the continuous gas AUs. Table 1 lists input data used to calculate volumes of undiscovered resources in the four AUs.

The Haynesville Western Shelf Carbonate Gas and Oil AU is bounded on the north and west by fault systems and shallow-marine carbonates and reefs that extend basinward to the depositional shelf-break (Salvador, 1991; Hammes and others, 2011; Cicero and Steinhoff, 2013).

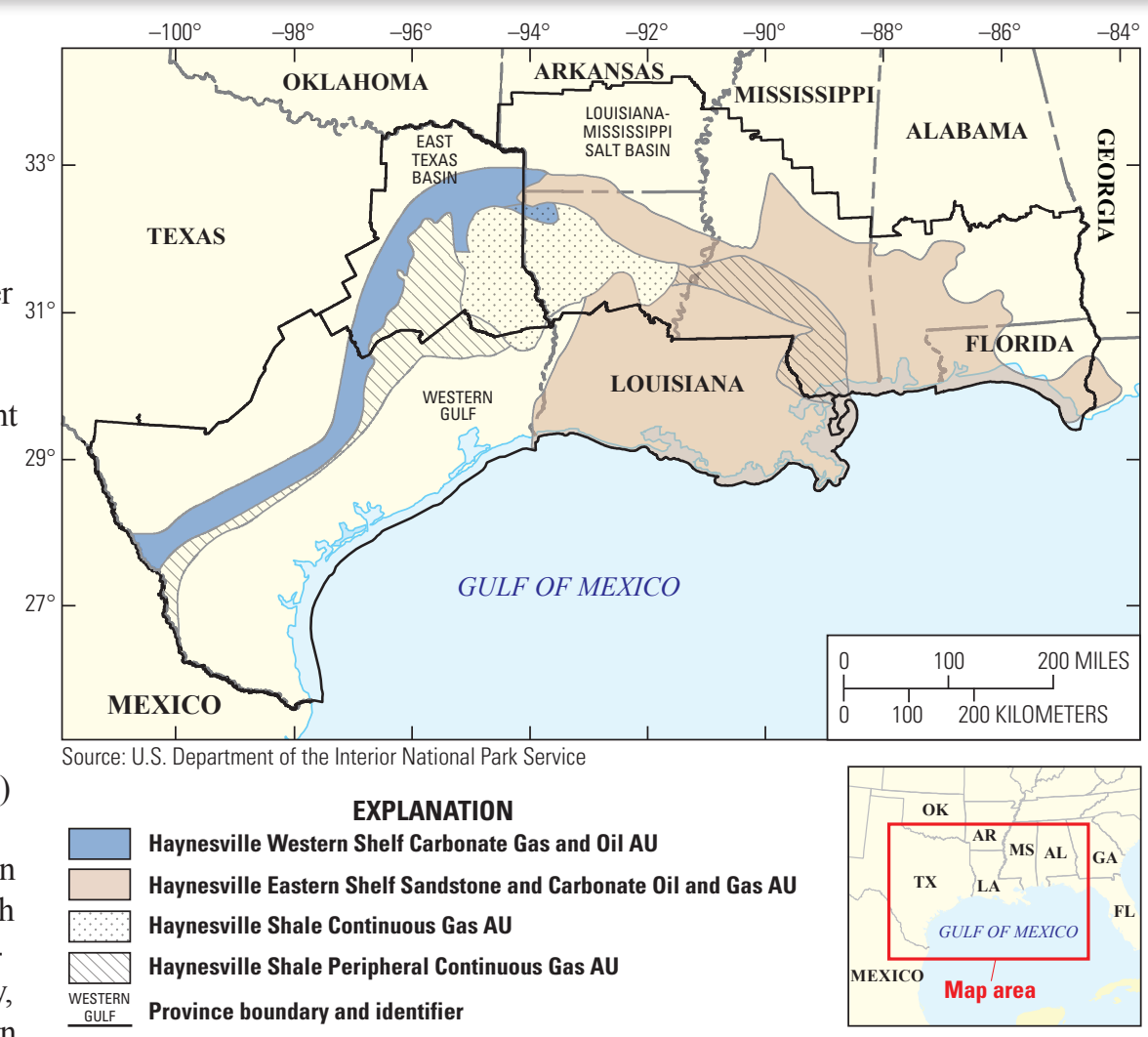

Figure 1. Map showing approximate boundaries for the four assessment units (AUs) in the Upper Jurassic Haynesville Formation.

The Haynesville Eastern Shelf Sandstone and Carbonate Oil and Gas AU is bounded on the east and north by fault systems and lithofacies that extend basinward to the continental shelf-break and beyond (Salvador, 1991; Cicero and Steinhoff, 2013). Reservoirs are transitional from fluviodeltaic and paralic deposits in the northeast (Montgomery, 1993b) to marine deposits basinward on the shelf, slope, and basin floor (Cicero and Steinhoff, 2013).

The Haynesville Shale Continuous Gas AU is defined by mudstone in the greater Sabine uplift area where restricted marine circulation allowed the accumulation and preservation of organic-rich mudstone (Hammes and others, 2011). The southern boundary of the mudstone is at the continental shelf-break (Cicero and Steinhoff, 2013).

The Haynesville Shale Peripheral Continuous Gas AU, present in two separate parts of the study area, is defined by lithofacies peripheral to the Haynesville Shale Continuous Gas AU (Salvador, 1991; Hammes and others, 2011; Cicero and Steinhoff, 2013). The southern limit of the Haynesville Shale Peripheral Continuous Gas AU is defined by the continental shelf-slope break. 


\section{Undiscovered Resources Summary}

The USGS assessed undiscovered, technically recoverable resources for two conventional oil and gas AUs and two continuous AUs in the Haynesville Formation. The estimated mean totals for oil and gas resources are 1,103 million barrels of oil (MMBO), or 1.1 billion barrels of oil, with an F95-F5 range from 286 to 2,508 MMBO; 195,797 billion cubic feet of gas (BCFG), or 195.8 trillion cubic feet of gas, with an F95-F5 range from 96,267 to 340,963 BCFG; and 866 million barrels of natural gas liquids (MMBNGL) with an F95-F5 range from 304 to $1,747 \mathrm{MMBNGL}$ (table 2).

Table 1. Key assessment input data for two conventional and two continuous assessment units (AUs) in the Haynesville Formation of Alabama, Arkansas, Florida, Louisiana, Mississippi, and Texas.

[AU, assessment unit; \%, percent; EUR, estimated ultimate recovery per well; MMBO, million barrels of oil; BCFG, billion cubic feet of gas. The average EUR input is the minimum, median, maximum, and calculated mean. Shading indicates not applicable]

\begin{tabular}{|c|c|c|c|c|c|c|c|c|}
\hline \multirow{2}{*}{ Assessment input data } & \multicolumn{4}{|c|}{ Haynesville Western Shelf Carbonate Gas and Oil AU } & \multicolumn{4}{|c|}{ Haynesville Eastern Shelf Sandstone and Carbonate Oil and Gas AU } \\
\hline & Minimum & Median & Maximum & Calculated mean & Minimum & Median & Maximum & Calculated mean \\
\hline Number of oil fields & 0 & 4 & 10 & 4.2 & 1 & 75 & 250 & 80.7 \\
\hline Number of gas fields & 1 & 50 & 150 & 53.2 & 1 & 150 & 500 & 161.5 \\
\hline Sizes of oil fields (MMBO) & 0.5 & 1.0 & 10 & 1.3 & 0.5 & 1.5 & 1,600 & 13.6 \\
\hline Sizes of gas fields (BCFG) & 3 & 6 & 300 & 11.6 & 3 & 18 & 10,000 & 118.1 \\
\hline AU probability & 1.0 & & & & 1.0 & & & \\
\hline \multirow{2}{*}{ Assessment input data } & \multicolumn{4}{|c|}{ Haynesville Shale Continuous Gas AU } & \multicolumn{4}{|c|}{ Haynesville Shale Peripheral Continuous Gas AU } \\
\hline & Minimum & Mode & Maximum & Calculated mean & Minimum & Mode & Maximum & Calculated mean \\
\hline Potential production area of AU (acres) & $4,017,000$ & $5,565,000$ & $10,779,000$ & $6,787,000$ & 10,000 & $5,116,000$ & $14,034,000$ & $6,386,667$ \\
\hline Average drainage area of wells (acres) & 80 & 100 & 140 & 107 & 60 & 100 & 180 & 113 \\
\hline Success ratio $(\%)$ & 50 & 70 & 90 & 70 & 10 & 50 & 90 & 50 \\
\hline Average EUR (BCFG) & 2.0 & 3.0 & 5.0 & 3.093 & 0.5 & 1.5 & 3.0 & 1.562 \\
\hline AU probability & 1.0 & & & & 1.0 & & & \\
\hline
\end{tabular}

Table 2. Assessment results for two conventional and two continuous assessment units (AUs) in the Haynesville Formation of Alabama, Arkansas, Florida, Louisiana, Mississippi, and Texas.

[MMBO, million barrels of oil; BCFG, billion cubic feet of gas; NGL, natural gas liquids; MMBNGL, million barrels of natural gas liquids. Results shown are fully risked estimates. For gas accumulations, all liquids are included under the natural gas liquids category. F95 represents a 95-percent chance of at least the amount tabulated; other fractiles are defined similarly. Fractiles are additive under the assumption of perfect positive correlation. Shading indicates not applicable]

\begin{tabular}{|c|c|c|c|c|c|c|c|c|c|c|c|c|c|c|}
\hline \multirow{3}{*}{$\begin{array}{l}\text { Total petroleum system and } \\
\text { assessment units (AUs) }\end{array}$} & \multirow{3}{*}{$\begin{array}{c}\mathrm{AU} \\
\text { probability }\end{array}$} & \multirow{3}{*}{$\begin{array}{c}\text { Accumulation } \\
\text { type }\end{array}$} & \multicolumn{12}{|c|}{ Total undiscovered resources } \\
\hline & & & \multicolumn{4}{|c|}{ Oil (MMBO) } & \multicolumn{4}{|c|}{ Gas (BCFG) } & \multicolumn{4}{|c|}{ NGL (MMBNGL) } \\
\hline & & & F95 & F50 & F5 & Mean & F95 & F50 & F5 & Mean & F95 & F50 & F5 & Mean \\
\hline \multicolumn{15}{|c|}{ Upper Jurassic-Cretaceous-Tertiary Composite Total Petroleum System } \\
\hline \multirow{2}{*}{$\begin{array}{l}\text { Haynesville Western Shelf Carbonate } \\
\text { Gas and Oil AU }\end{array}$} & \multirow{2}{*}{1.0} & Oil & 2 & 5 & 10 & 5 & 3 & 7 & 15 & 7 & 0 & 1 & 2 & 1 \\
\hline & & Gas & & & & & 275 & 573 & 1,102 & 616 & 2 & 5 & 11 & 6 \\
\hline \multirow{2}{*}{$\begin{array}{l}\text { Haynesville Eastern Shelf Sandstone } \\
\text { and Carbonate Oil and Gas AU }\end{array}$} & \multirow{2}{*}{1.0} & Oil & 284 & 927 & 2,498 & 1,098 & 378 & 1,261 & 3,648 & 1,535 & 39 & 129 & 375 & 157 \\
\hline & & Gas & & & & & 6,915 & 17,364 & 37,109 & 19,033 & 61 & 159 & 357 & 178 \\
\hline Total conventional resources & & & 286 & 932 & 2,508 & 1,103 & 7,571 & 19,205 & 41,874 & 21,191 & 102 & 294 & 745 & 342 \\
\hline Haynesville Shale Continuous Gas AU & 1.0 & Gas & & & & & 78,970 & 124,335 & 198,614 & 129,663 & 176 & 366 & 678 & 389 \\
\hline $\begin{array}{l}\text { Haynesville Shale Peripheral } \\
\text { Continuous Gas AU }\end{array}$ & 1.0 & Gas & & & & & 9,726 & 38,906 & 100,475 & 44,943 & 26 & 111 & 324 & 135 \\
\hline Total continuous resources & & & & & & & 88,696 & 163,241 & 299,089 & 174,606 & 202 & 477 & 1,002 & 524 \\
\hline Total undiscovered resources & & & 286 & 932 & 2,508 & 1,103 & 96,267 & 182,446 & 340,963 & 195,797 & 304 & 771 & 1,747 & 866 \\
\hline
\end{tabular}

\section{References Cited}

Cicero, A.D., and Steinhoff, Ingo, 2013, Sequence stratigraphy and depositional environments of the Haynesville and Bossier shales, east Texas and north Louisiana, chap. 3 of Hammes, Ursula, and Gale, Julia, eds., Geology of the Haynesville gas shale in east Texas and west Louisiana, U.S.A.: American Association of Petroleum Geologists Memoir 105, p. 25-46.

Hammes, Ursula, Hamlin, H.S., and Ewing, T.E., 2011, Geologic analysis of the Upper Jurassic Haynesville shale in east Texas and west Louisiana: American Association of Petroleum Geologists Bulletin, v. 95, no. 10, p. 1643-1666.

Mancini, E.A., Peng, Li, Goddard, D.A., and Zimmerman, R.K., 2006, Petroleum source rocks of the onshore interior salt basins, north central and northeastern Gulf of Mexico: Gulf Coast Association of Geologic Societies Transactions, v. 55, p. 486-504.

Montgomery, Scott, 1993a, Cotton Valley lime of east Texas-New pinnacle reef play in the Late Jurassic: Petroleum Frontiers, v. 10, no. $2,55 \mathrm{p}$.

Montgomery, Scott, 1993b, Haynesville of southern Alabama-A new Jurassic play in the eastern Gulf: Petroleum Frontiers, v. 10, no. 1, $65 \mathrm{p}$.

Salvador, Amos, 1991, Triassic-Jurassic, in Salvador, Amos, ed., The Gulf of Mexico basin, part of The geology of North America: Boulder, Colo., The Geological Society of America, v. J, p. 131-180.

\section{For More Information}

Assessment results are available at the USGS Energy Resources Program website at http://energy.usgs.gov.

\section{Haynesville Formation Assessment Team}

Stanley T. Paxton, Janet K. Pitman, Scott A. Kinney, Nicholas J. Gianoutsos, Ofori N. Pearson, Katherine J. Whidden, Russell F. Dubiel, Christopher J. Schenk, Lauri A. Burke, Timothy R. Klett, Heidi M. Leathers-Miller, Tracey J. Mercier, Seth S. Haines, Brian A. Varela, Phuong A. Le, Thomas M. Finn, Stephanie B. Gaswirth, Sarah J. Hawkins, Kristen R. Marra, and Marilyn E. Tennyson 